\title{
The Extent of Informational Efficiency in the Credit Default Swap Market: Evidence from Post Announcement Returns
}

\author{
Nicole Thorne Jenkins ${ }^{\mathrm{a}}$, Michael Kimbrough ${ }^{\mathrm{b}}$, Juan Wang ${ }^{\mathrm{c}}$ \\ ${ }^{a}$ Owen School of Management, Vanderbilt University; \\ 401 21st Ave. South; Nashville, TN 37203-2422 \\ ${ }^{\mathrm{b}}$ Robert H. Smith School of Business, University of Maryland \\ 4332 M Van Munching Hall; College Park, MD 20742-1815 \\ ${ }^{\mathrm{c}}$ Singapore Management University \\ 60 Stamford Road Singapore, 178900
}

Current Draft: January 2011

\begin{abstract}
Building on the classic definition of semi-strong form market efficiency where previously released public information does not predict future returns, we provide evidence on the informational efficiency of the credit default swap (CDS) market by examining the relationship between subsequent movements in CDS prices and previously announced accounting information. We find that quarterly earnings surprises and quarterly accruals, both of which have been shown to be the source of stock market anomalies, generate systematic patterns in subsequent CDS returns in both the pre- and post-crisis periods, consistent with the CDS market being less than fully efficient with information. We find, however, that the nature of these patterns differs between the two periods. Specifically, our pre-crisis results are consistent with the CDS market being insufficiently attentive to the information in both earnings surprises and accruals. By contrast, our post-crisis results are consistent with the CDS market overreacting to the information in earnings and accruals. The relation between subsequent CDS returns and prior accounting information generally declines with firm size, suggesting that, as in the equity market, firms with richer information environments are less susceptible to anomalies. The anomalous behavior of CDS prices is strongest for firms with speculative grade debt, perhaps because accounting information is most relevant in assessing default risk for this set of firms and, hence, suboptimal use of this information is most economically consequential for these firms.
\end{abstract}

EFM classification: 200, 440, 710

Keywords: credit default swaps; market efficiency; default risk; post earnings announcement drift; accrual anomaly Data: All data are publically available.

Corresponding author: Tel (615) 343-0553 office; Fax (615) 343-7177 (Nicole Thorne Jenkins)

Tel (301)-405-8522 office; Fax (301)-314-9414 (Michael Kimbrough)

Tel 68280986 (Juan Wang)

E mail addresses: $\quad$ Nicole.Jenkins@vanderbilt.edu (Nicole Thorne Jenkins) Mkimbrough@rhsmith.umd.edu (Michael Kimbrough) juanwang@smu.edu.sg (Juan Wang) 


\section{Introduction}

A growing body of literature examines the role of accounting information in the credit market. Several studies demonstrate the relevance of accounting information for the pricing of credit risk by documenting long window associations between earnings and alternative measures of credit risk such as CDS spreads, bond returns and credit ratings (e.g. Callen et al. 2009, Easton 2009 and Jiang 2008). Several other studies demonstrate the credit market's specific reliance on earnings information when revising its assessment of credit risk by documenting that credit markets react over short-windows to earnings announcements (e.g. Hotchkiss and Ronen 2002, Easton et al. 2009, Defond and Zhang 2009, and Callen et al. 2009). Evidence from prior studies that the credit market responds immediately to the release of accounting information suggests a fair degree of informational efficiency in the credit market with respect to this information. However, the exclusive focus on credit markets' initial reactions to accounting information in prior studies does not permit a complete assessment of the informational efficiency of credit markets because it is possible for initial reactions to be incomplete or inappropriate. Therefore, we seek to provide more comprehensive evidence on the informational efficiency of the credit market. Building on the classic definition of semi-strong form market efficiency where previously released public information does not predict future returns, we provide evidence on the informational efficiency of the credit default swap (CDS) market by examining the relationship between subsequent movements in CDS prices and previously announced accounting information.

The question of the degree of informational efficiency in the CDS market is one of some urgency given the apparent failure of the CDS market to appropriately price the default risk of mortgage obligations during the recent economic crisis. Skepticism about the functioning of the CDS market led to greater regulation of the derivative market as part of the Dodd-Frank Wall 
Street Reform and Consumer Protection Act of 2010. Although it is widely acknowledged that the CDS market performed poorly in pricing mortgage default risk, it is not clear ex ante that this same tendency towards mispricing extends to corporate debt. While the significant opacity about the true nature of mortgages underlying collateralized debt obligations likely hindered the credit market's ability to accurately price default risk, the degree of regulation, disclosure requirements, and audit scrutiny to which issuers of corporate debt are subject contribute to a richer information environment that may facilitate better pricing of default risk in the corporate debt market. On the other hand, given that the U.S. stock market has historically experienced anomalies such as the post-earnings announcement drift (e.g. Bernard and Thomas 1989; Collins and Hribar, 2000) and the accrual anomaly (e.g. Sloan, 1996 and Collins and Hribar, 2000), it is not obvious that the CDS market for corporate debt would be immune from mispricing. Moreover, the increasingly speculative use of CDSs raises the probability of mispricing. Therefore, the degree of informational efficiency of the CDS market is ultimately an empirical question.

Using daily CDS prices from Bloomberg for a sample of CDS contracts related to 437 firms that announced earnings for quarters ending December 31, 2003 through March 31, 2009, we examine the relation between post-announcement CDS returns and quarterly deciles formed on the basis of seasonally differenced earnings and accruals, both of which have been shown to be associated with anomalous stock price movements (e.g. Bernard and Thomas, 1989 and Sloan 1996, Collins and Hribar, 2000). ${ }^{1}$ In addition to providing results for the full sample period, we provide separate results for pre-crisis quarters, which are those quarters prior to September 2008

\footnotetext{
${ }^{1}$ We obtain daily CDS prices from Bloomberg, which has the advantage of allowing us to capture the change in CDS spreads on an individual security basis rather than the change in issue price on two different CDSs issued on the same reference asset as done in prior work (Callen et al. 2009). Hence, use of the Bloomberg pricing data allows us to directly capture the change in estimated financial distress in a short window around the release of accounting information.
} 
and post-crisis quarters which correspond to quarters ending on or subsequent to September $2008 .^{2}$

We find that both earnings surprises and accruals generate systematic patterns in subsequent CDS returns in both the pre- and post-crisis periods, consistent with the CDS market being less than fully efficient with information. However, the nature of these patterns differs prior to and subsequent to September 2008. Specifically, our pre-crisis results are consistent with the CDS market being insufficiently attentive to the information in both earnings surprises and accruals. By contrast, our post-crisis results are consistent with the CDS market overreacting to the information in earnings and accruals.

The relation between subsequent CDS returns and prior accounting information generally declines with firm size, suggesting that, as in the equity market, firms with richer information environments are less susceptible to anomalies. The anomalous behavior of CDS prices is strongest for firms with speculative grade debt, perhaps because accounting information is most relevant in assessing default risk for this set of firms and, hence, suboptimal use of this information is most economically consequential for these firms.

Interestingly, post-announcement CDS returns tend to drift upward for all deciles formed in the pre-crisis period, indicating that the market was generally sluggish in fully pricing default risk irrespective of the nature earnings or accruals information. By contrast, post-announcement CDS returns tend to drift downward for all deciles formed in the post-crisis period, indicating that the market generally tended to have excessively high initial assessments of default risk regardless of the nature of earnings or accrual information. These patterns are consistent with

\footnotetext{
${ }^{2}$ Lehman Brothers filed for bankruptcy and the federal government bailed out AIG, two major players in the CDS market, in September 2008.
} 
claims that credit markets did not sufficiently price default risk in the pre-crisis period and may have become excessively conservative in the wake of the crisis.

Our study makes a number of contributions. First, we add to the current understanding of how the credit markets use accounting information. While prior work has focused exclusively on initial credit market responses to earnings announcements, our focus on post-announcement CDS returns provides greater insight on the appropriateness and completeness of the credit market's responses to accounting information. In addition, we add to the literature on accounting-based anomalies by showing that they extend beyond the equity market. Finally, our evidence on the informational efficiency of the CDS market is likely to be of interest to policymakers. Specifically, the fact that we find evidence of inefficiency in the CDS market in the context of corporate debt, where information is highly regulated and transparent, suggests that general concerns about how this market functions may be justified. Moreover, our contrasting findings for pre- versus post-crisis quarters are consistent with claims that the credit markets were lax in general prior to the crisis and unduly conservative thereafter.

The remainder of this study proceeds as follows. In Section 2, we discuss prior research on the informational efficiency of the credit market and accounting-based anomalies. We also provide relevant institutional details on the structure of the CDS market. We present our sample selection procedures and describe the data in Section 3. Section 4 contains a discussion of our empirical results and we conclude in Section 5.

\section{Prior Research and Discussion of Credit Default Swap Market}

\subsection{The Informational Efficiency of the Credit Market}

A number of prior studies examine the extent of informational efficiency in the credit market and provide contrasting findings. Katz (1974) examines the responsiveness of bond 
prices to credit rating changes and finds that the debt market does not appear to anticipate debt rating changes and that bond prices respond sluggishly to the announcement of debt rating changes, calling into question the efficiency of the debt market. Norden and Weber (2004) examine the timeliness of CDS spreads to the announcement of debt rating changes and, by contrast, conclude that CDS spreads both anticipate and respond quickly to debt rating changes. Hotchkiss and Ronen (2002) examine the statistical properties of intraday bond returns and conclude that the bond market is similarly efficient to the equity market. The focus of these studies is on the timeliness element of market efficiency but they provide little evidence on the appropriateness and completeness of the market's response to information events. Moreover, these studies do not focus on accounting information per se.

Using event study methodology, Hotchkiss and Ronen (2002), Easton et al (2009), Defond and Zhang (2009) and Callen et al. (2009) provide some insight on the efficiency of the credit market with respect to accounting information in that they show that debtholders respond immediately to earnings announcements, which is an essential element to establishing informational efficiency in the debt market. ${ }^{3}$ However, given that initial reactions can be suboptimal, these studies provide limited insight on the appropriateness and completeness of the credit market's initial responses, which are also relevant factors in assessing the degree of informational efficiency. We, therefore, examine the appropriateness and completeness of credit market responses to accounting information in this study.

\footnotetext{
${ }^{3}$ Specifically, Hotchkiss and Ronen (2002), Easton et al. (2009) and Defond and Zhang (2009) document a significant positive association between short-window bond returns surrounding earnings announcements and earnings surprises while Callen et al. (2009) document a negative relation between changes in credit default swap spreads surrounding earnings announcements and earnings surprises.
} 
In undertaking this examination, we build on the classic definition of semi-strong form market efficiency where previously released public information does not predict future returns . Hence, we examine the relationship between subsequent movements in CDS prices and previously announced seasonally differenced quarterly earnings and quarterly accruals. We focus on seasonally differenced earnings and quarterly accruals because prior accounting research demonstrates the relevance of earnings and accruals for pricing in the credit market. ${ }^{4}$ In addition, both measures have been the source of anomalous stock price behavior, as discussed below. Therefore, it is important to know whether the credit market is susceptible to similar anomalies with respect to this information.

\subsection{Accounting-Based Anomalies and their Potential Existence in the Debt Market}

In testing the degree of informational efficiency in the debt market, we focus on two enduring accounting-based anomalies that have been documented in the equity market: (1) Postearnings announcement drift (PEAD) and the accrual anomaly first documented by Sloan (1996). With respect to PEAD, Ball and Brown (1968) provided the first indication that the market does not fully react to earnings at the time they are announced by demonstrating that returns tend to drift for a considerable period of time subsequent to earnings announcements. Bernard and Thomas (1989) provide evidence that the drift is attributable to the market not fully incorporating the predictable time series properties of earnings when responding to earnings. With respect to the accrual anomaly, Sloan (1996) shows that the accrual component of earnings is significantly less persistent than the cash flow component and that a profitable trading strategy can be formed based on the relative magnitude of the accrual component, consistent with equity

\footnotetext{
${ }^{4}$ For example, Callen et al. (2009) documents negative associations between the level of earnings and the magnitude of CDS spreads, consistent with higher earnings being associated with lower perceptions of default likelihood for the reference companies. In addition, Callen et al. (1999) and Easton (2009) document long window associations between changes in CDS spreads and bond returns, respectively, and earnings changes, indicating that earnings captures information relevant to the pricing of debt and to the assessment of default likelihood.
} 
investors being insufficiently attentive to the differential persistence of the accrual and cash flow components to earnings.

The extent to which these two anomalies will be observed in the credit market is not obvious. If these anomalies are the result of information processing biases to which equity and debt investors are similarly susceptible, we would expect to see these anomalies in the credit market. On the other hand, earnings serves two different roles in the credit versus equity markets. In the debt market, earnings is informative about changes in the likelihood of default over finite, relatively short horizons whereas in the equity market, earnings is potentially informative about revisions in the infinite stream of expected future cash flows.

\subsection{Structure of the CDS Market}

We focus on the CDS market for several reasons. First, the CDS market is economically significant relative to the global economy. ${ }^{5}$ Second, relative to other outputs such as bond prices or credit ratings, CDS prices are conceptually pure, frequently updated measures of default risk. ${ }^{6}$ Therefore, we believe an examination of the functioning of the CDS market outside the specialized CDO setting is warranted.

The CDS market began in the 1990s as banks were developing new ways of breaking up traditional securities to off-load parts of their credit risk. Under a CDS contract, the issuer agrees to assume the financial loss if a credit event related to a specified underlying debt occurs in

\footnotetext{
${ }^{5}$ From 2002 to 2007 the CDS market grew from \$2 trillion to \$62.2 trillion (ISAD 2010).As of 2009 the worldwide bond market was estimated at \$82.2 trillion with the US market representing \$34.7 trillion on daily trading of \$822 billion. Approximately $\$ 13.4$ trillion of total US debt is T-bills and Municipals. On an annual basis, the global equity market hovers around $\$ 40-50$ trillion, about half of the debt market.

${ }^{6}$ Easton et al. (2009) utilized bond yields in determining the credit market's reaction to accounting information; however, bond yields are influenced by many factors other than default risk such as interest rate risk and liquidity risk. Research has shown that CDS spreads are better indicators of financial distress than are bond yields, they lead the bond markets, and are more liquid during times of increased risk (Kiff et al. 2009 and Becker 2009). The notion that CDS spreads are reliable indicators of distress in the referenced asset is widely accepted in research and the industry.
} 
exchange for an annual premium referred to as the spread. ${ }^{7}$ The spread is calculated as a fraction of the underlying debt's notional value. The fraction is calculated as the annualized premiumannual premium divided by 360 days. ${ }^{8}$ The annual payment is fixed for the initial buyer and is generally paid quarterly until a specific pre-defined credit event occurs or the contract matures. By construction, the spread is positively correlated with the credit quality of the reference entity on which the CDS is written. There are no limits on the size of a CDS swap contract, though most contracts fall between $\$ 10$ and $\$ 20$ million. They are traded over the counter (OTC) at varying maturities; however, the 5-year contract is the most common and therefore, the most liquid. Because the CDS market is quite active, the stated selling price of CDSs vary based on the likelihood of the credit event occurring. ${ }^{9}$

If a credit event occurs, the issuer has the obligation to settle the contract by paying the buyer the incurred loss. CDSs may require physical settlement where the buyer must present the bond at the point of settlement in exchange for cash. If cash settlement is agreed upon, the buyer will receive the difference between the bond value at the time of settlement and the bond's nominal value in cash. ${ }^{10}$ In theory, the post default recovery value at the time of settlement is the difference in value of the reference security and its stated face value. However, because the referenced asset (corporate bond) is likely not trading, this value is difficult to determine in practice.

\footnotetext{
${ }^{7}$ The credit events covered by CDS include bankruptcy, obligation acceleration, obligation acceleration, obligation default, failure to pay, repudiation or moratorium, and restructuring (in 2009, US contracts eliminated this as a potential trigger event).

${ }^{8}$ CDS spreads are denominated in basis points and represents a percentage of the notional amount. Thus, a CDS with a spread of 100 would cost $1 \%$ of the face amount of the underlying asset.

${ }^{9}$ A CDS is purchased by an initial buyer who may sell the CDS in the future at a new prevailing price which represents the credit worthiness of the referenced asset on that date. Over the life of the CDS there can be multiple players in the chain of buyers and sellers; however, it is only the counterparty at the beginning of the chain (the original seller) and at the end (the last buyer) who have the obligation and protection, respectively. The entities in between are merely collecting the difference in the annual premiums that they are obligated to pay and those that they contracted to receive.

${ }^{10}$ Physical settlement declined from 2004 to 2005 from 86\% to 73\% being replaced with cash settlement which has become more widely used due to the use of auction settlement procedures in standard CDS contracts (BBA 2006).
} 
Early on, CDSs were primarily used to hedge risk. However, they soon gave way to speculation which fueled the market's growth. CDSs allow credit risk to be hedged separately from interest rate risk. Unlike securitizations, CDSs do not require prefunding on the part of the seller. Moreover, the buyer can maintain their existing credit portfolio and customer relationships while changing the portfolio's risk exposure. CDS contracts are similar to insurance policies where one party assumes the risk and the other pays a premium. However, CDSs can differ from insurance contracts in that it is not necessary for the purchaser to own the item being insured. The increasingly speculative nature of the CDS market increases the probability of mispricing and further motivates our examination.

\section{Sample Selection and Descriptive Statistics}

\subsection{Data Collection}

We begin our data collection by constructing a sample of quarterly earnings announcements of all publicly traded US firms from COMPUSTAT starting in 2003. We then collect all CDS data from Bloomberg for these firms. Bloomberg maintains daily trading prices on specific CDSs written on referenced assets. The prices reported by Bloomberg are intraday prices that are the arithmetic mean of prices received by the agency during the previous rolling 24 hours. We require that each firm in our sample have the necessary financial data from COMPUSTAT to perform our main analyses. We eliminate all contracts not denominated in US dollars. These procedures yield a sample of 11,199 firm-quarter-contract observations which consist of 2,250 CDS contracts written on 437 unique firms from 2003 through March 31, 2009.

Unlike Callen, Livnat and Segal (2009), whose CDS price data only allows them to calculate CDS returns by "by comparing two different contracts with the same contractual features for the same reference entity”, our use of high frequency CDS spread data from Bloomberg allows us to 
capture the average daily prices for individual CDS instruments, thereby reducing the amount of measurement error in the return calculation. Moreover, the higher frequency data provided by Bloomberg allows us not only to calculate short-window returns but also post-announcement returns, which are necessary for assessing the appropriateness and completeness of the initial reaction.

\subsection{Descriptive Statistics}

Table 1 reports our descriptive analyses for the sample (Panel A) as well as our SUE (Panel B) and accruals (Panel C) deciles. The firms in our sample are large with a mean (median) market capitalization of \$36.1 (\$14.0) million. Approximately 43\% (0.0\% median) of our sample has speculative grade debt (SPECULATIVE) — credit rating below BBB+ which is consistent with Callen et al. (2009). On average, both the Standardized Unexpected Earnings (SUE) and accrual (ACCRUALS) are negative at -0.003 and -0.015 , respectively. We find that the four day return around the earnings announcement (CDSTRETANN) is $4.2(0.0)$ basis points on average (median). The corresponding 60 day return (CDSRET60) increases to 19 basis points.

In Panel B we examine the variables described above across SUE deciles. No consistent monotonic relations seem to emerge from the data. However, the short window returns (CDSTRETANN) appear to be consistently declining as the SUE deciles increase, implying that default likelihood is decreasing as SUE deciles increase. Moreover, there appears to be more income decreasing accrual in the smallest two SUE deciles. By contrast there are higher cash levels in the largest three SUE deciles. Taken together, these relations indicate that the extreme negative (positive) SUEs contain the largest income decreasing accruals (positive cash flows). Smaller firms and more speculative firms seem to populate the extreme deciles of the SUE ranking. 
The accrual decile rankings are reported in Panel C. By construction, cash is decreasing monotonically as the accrual deciles increase. Similar to the SUE rankings, the largest increase in short window returns (CDSTRETANN) is in the smallest accrual deciles implying that default risk is increasing in income decreasing accruals. In addition, the extreme deciles contain the firms that are both the smallest (SIZE) and the lowest rated (SPECULATIVE).

Because our sample spans the US financial crisis we consider two subsamples in addition to our full sample. Following the bailout of AIG in September 2008, the scrutiny of the CDS market and the manner in which the contracts were written and cleared changed substantially. Specifically, the bailout of AIG led to calls for increased transparency and regulations. In November 2008, The Depository Trust \& Trading Clearinghouse which accounts for the vast majority of CDS trade confirmations began releasing market data on outstanding CDS notional amounts. By the first quarter of 2009 CDSs written on Lehman Brothers had been settled and the CDS market contracted. At that same time standardization of CDS contracts occurred in an effort to prevent legal disputes and to facilitate payouts. The InterContinental Exchange and Chicago Mercantile Exchange began operating clearing houses to act as a central counterparty to both sides of CDS transactions which resulted in a reduction in the counterparty risk faced by buyers and sellers. Given these changes, we designate the pre-crisis sample as firm-quarters prior to September 2008 and the post-crisis sample as all firm-quarters including and subsequent to September 2008 and examine whether our findings differ across the two periods.

\section{Results}

\subsection{Initial Market Reaction to Earnings Announcement.}

In Table 2 we estimate the short window market reaction (CDSRETANN) around earnings announcement dates as a function of the SUE (DSUE) and accrual (DACCRUAL) rankings 
within quarter. Panel A contains our results for the SUE. The coefficient on the SUE ranking for the full sample is -0.114 (p-value $<0.001$ ), indicating that unexpected increases (decreases) in earnings lead to lower (higher) CDS spreads—default likelihood. This negative relation is consistent with findings from Callen et al. (2009) using a different data source for CDS prices and is similar to results in the equity market where stock price is positively correlated with unexpected earnings. ${ }^{11}$ The relation between DSUE and CDS returns is significantly negative for both the pre and post-crisis subsamples at -0.095 (p-value $<0.001$ ) and -0.196 (p-value $<0.001$ ), respectively. However, the market reaction in the post-crisis period is significantly larger than in the pre-crisis period (p-value $<0.001$ ), providing some support for the possibility of a regime shift subsequent to the financial crisis.

Panel B of Table 2 reports our results for within quarter accrual rankings and short window market returns. For the full sample, the CDS market's initial response is negatively related to the accrual ranking. In other words, larger income-increasing accruals are associated with downward revisions in default likelihood. The CDS market appears to reward firms for the non-cash portion of earnings. Separate analysis of the two sub periods provides interesting insights. In the pre-crisis subsample, the relation is not different from zero, suggesting that the CDS market did not respond to the accrual (i.e. non-cash) portion of earnings, consistent with conventional wisdom that cash flows are more relevant to creditors. By contrast, the relation is significantly negative in the post-crisis period (coefficient=-0.223; p-value $<0.001$ ), thereby driving the full sample results (i.e. the difference in the coefficient between the two sub periods is significant at $\mathrm{p}<0.001)$. Hence, it appears that the CDS market only began to appreciate the non-cash portion of earnings in the post-crisis period.

\footnotetext{
${ }^{11}$ Increases in stock prices represent good news for the firm in the equity market. In the CDS market, the direction of spreads is reversed. In particular, decreases in CDS spreads represent good news for the firm in that their default likelihood has decreased.
} 
Taken as a whole, our findings that the market responds contemporaneously to the release of earnings and accrual information are consistent with those of Callen et al. (2009). Our findings of significant differences in the magnitude of these responses in the pre- and post-crisis periods raise the possibility that the initial CDS responses to earnings and accruals were suboptimal in one or both periods. Our post-announcement analysis in the next section provides greater insight into this possibility.

\subsection{Completeness of the Market's Response to Earnings News}

Figure 1 depicts the CDS market's movement subsequent to its initial reaction to earnings surprises. Panel A of Figure 1 is a graph of SUE ranked deciles for the entire sample period for 90 days subsequent to two days after the earnings announcement. The returns for deciles 2,3 , and 4 exhibit a generally upward trend over the post-announcement period while returns for decile 10 exhibit a generally downward trend. These patterns are consistent with delayed penalties to bad news deciles and a delayed reward to the best news firm, consistent with patterns of underreaction historically seen in the post-earnings announcement drift literature. The exception to this overall pattern is the initial upward and ultimate downward drift for decile 1 (the worst news firm).

A clearer picture emerges when the two sub periods are analyzed separately. Panel B presents the pre-crisis results. An interesting observation is that subsequent spreads tend to drift upward during the pre-crisis period for all deciles. This finding indicates that, irrespective of the nature of earnings news, the CDS market was generally slow to fully price increases in default risk in the pre-crisis period, consistent with popular claims. Nevertheless, the subsequent returns do appear to vary systematically with SUE deciles. The magnitude of the upward drift is largest for the smallest deciles, with the upward drift being most pronounced for decile 1 . This result 
indicates that the negative relation between SUE deciles and announcement period returns that we document in Table 2 represents an underreaction since the negative relation persists in the post-announcement period.

Panel C of Table 1 depicts the drift for the post-crisis subsample indicating a downward drift for all ten SUE deciles, in stark contrast to the pre-crisis period. This finding indicates that, irrespective of the nature of earnings news, the CDS market assigned excessively high initial assessments of default risk, consistent with popular claims of excessively tight credit markets in the post-crisis period. With respect to patterns in subsequent returns and decile rankings, the most notable observable shift in the post-crisis period is that decile 1 , which is associated with the largest upward drift in the pre-crisis period is associated with the largest downward drift in the post-crisis period. Hence, while the market appears to have initial assessments of default risk that are too low for this group in the pre-crisis period, it seems to have initial assessments of default risk that are too high for this group in the post-crisis period. Hence, the graphs are consistent with the CDS market overcompensating in the post-crisis period for the most extreme bad news firms.

We verify the intuition provided by Figure 1 using a regression framework. Table 3, Panel A presents the results of regressing post-announcement CDS returns (CDSRET60) on the SUE decile rank (DSUE). For the full sample, the relation is insignificant, corresponding to the murky picture for the full sample period presented in Panel A of Figure 1. The significantly negative relation in the pre-crisis period (coefficient $=0.276$; $\mathrm{p}$-value $<0.001$ ) is consistent with the picture provided in Panel B of Figure 1 that subsequent returns drift in the same general direction as the initial reaction, indicating that the initial reaction was incomplete (i.e. underreaction). By contrast, the relation is significantly positive in the post-crisis period (coefficient=1.333; p- 
value $<0.001$ ), which is consistent with subsequent returns drifting in the opposite direction of the initial reaction, indicating that the initial reaction was excessive (i.e. overreaction). This interpretation is consistent with the dramatic change in the pattern of drift for the lowest decile firms between the pre- and post-crisis periods depicted in Panel B of Figure 1 and with the higher negative association between earnings news and announcement period returns that we document in Table 2. Untabulated analysis suggests that the overreaction primarily relates to the

most extreme bad news firms (decile 1). When these firms are excluded from the regression of subsequent returns on SUE deciles, the relation is no longer positive and, in fact, becomes significantly negative $(\mathrm{p}<0.001)$.

Taken as a whole, the results in Figure 1 and Tables 2 and 3 suggest that, during the precrisis period, the CDS market exhibited an underreaction to earnings news similar to that which has been documented for stock prices. In response to the financial crisis, however, the CDS market appears to have overcompensated, reserving its most severe punishment for the most extreme bad news firms.

\subsection{Completeness of the Market's Response to the Accrual Component of Earnings}

Figure 2 depicts post-announcement CDS returns for accrual deciles. Panel A reports the graphs organized by accrual rank. The subsequent returns are largely flat for most deciles with the notable exception of decile 1 , which exhibits a prominent downward drift.

A clearer picture emerges when the two sub periods are analyzed separately. Panel B of Figure 2 depicts the pattern of post-announcement returns by accrual decile for the pre-crisis period. As we observed previously, subsequent returns tend to drift upward during the pre-crisis period for all deciles. This finding indicates that, irrespective of the nature of accrual information, the CDS market was generally slow to fully price default risk in the pre-crisis 
period, consistent with popular claims. Nevertheless, the subsequent returns do appear to vary systematically with accrual deciles, with the largest driver being the smallest accrual decile, which is associated with largest upward drift. Combined with the insignificant contemporaneous response to accrual information during the pre-crisis period that we document in Table 2, this finding suggests that the credit market had a tendency to ignore the unfavorable information in income-decreasing accruals, perhaps because the credit market overly fixated on cash flow. (Recall from Panel C of Table 1 that the lowest accrual decile had the largest cash flows.)

Panel C of Figure 2 depicts the pattern of post-announcement returns by accrual decile for the post-crisis period. As we observed previously, subsequent returns tend to drift downward during the post-crisis period for all deciles. This finding indicates that, irrespective of the nature of accrual information, the market likely assigned excessively high initial default risk assessments in the post-crisis period, consistent with popular claims. The most notable change in the relation between accrual deciles and subsequent returns is that the lowest accrual decile portfolios now exhibit the largest downward drift. This finding is consistent with the CDS market excessively punishing firms with income-decreasing accruals initially and correcting this excessive punishment over time. The market's sudden attentiveness to accruals in the post-crisis period that we document in Panel B of Table 2 is consistent with this interpretation.

We verify the intuition provided by Figure 2 using a regression framework. Table 3, Panel B presents the results of regressing post-announcement CDS returns (CDSRET60) on the ACCRUAL decile rank (DACCRUALS). For the full sample, the relation is insignificant, corresponding to the picture for the full sample period presented in Panel A of Figure 2. The significantly negative relation in the pre-crisis period (coefficient $=0.276$; p-value $<0.001$ ) is consistent with the smallest decile of accruals being associated with the largest upward drift as 
depicted in Panel B of Figure 2. By contrast, the relation is significantly positive in the postcrisis period (coefficient=1.333; p-value $<0.001$ ), which is consistent with subsequent returns drifting in the opposite direction of the initial reaction, indicating that the initial reaction was excessive (i.e. overreaction). This interpretation is consistent with the dramatic change in the subsequent return pattern for the lowest decile firms between the pre- and post-crisis periods depicted in Panels B\&C of Figure 2 and with the higher negative association between the accrual component of earnings and announcement period returns that we document in Table 2 . Untabulated analysis suggests that the overreaction primarily relates to the most extreme bad news firms.

Taken as a whole, the results in Figure 1 and Tables $2 \& 3$ suggest that, during the pre-crisis period, the CDS market exhibited an underreaction to accruals information, particularly for firms with the largest income-decreasing accruals. Given that these firms typically have the highest cash flow component, the CDS market's inattention to accruals for these firms may reflect the credit market's tendency to fixate on cash flows. In response to the financial crisis, however, the CDS market appears to have overcompensated, particularly by excessively penalizing firms with the largest income-decreasing accruals.

\subsection{The Effect of Firm Size and Credit Rating on Anomalous CDS Price Behavior}

We examine whether the anomalous behavior we document varies by firm size and by the firm's credit rating. We use firm size as a proxy for the strength of the firm's information environment and examine whether it affects the susceptibility of a firm's CDS prices to anomalous behavior. Our examination of the role of the firm's credit rating is based on past findings that the role of earnings is greater for firms with speculative debt. This finding suggests that the credit market may be more attentive to earnings information for firms that are nearer to 
default, thereby reducing the potential for anomalies. On the other hand, the greater importance of accounting information for firms near default means that the ramifications of inappropriately attending to this information are greater for this set of firms, thereby increasing the potential for anomalies.

Panels A and B of Table 4 report results for regressions of subsequent CDS returns and DSUE for subsamples of based on size in both pre- and post-crisis periods. ${ }^{12}$ In the pre-crisis period, the coefficient on DSUE is significantly negative for both the small and medium firms and insignificant for the largest firms. The difference in the coefficients between the smallest and largest firm groupings is also significant. Hence, the underreaction to earnings news in the precrisis period is not attributable to the largest firms. In the post-crisis period, the coefficient is again insignificantly different from zero for the largest firms while the coefficients on the small and medium firms are significantly positive. Moreover, the difference in coefficients between the largest and smallest firms is significant. Thus, overreaction to earnings news in the post-crisis period is not attributable to the largest firms. Taken collectively, the results suggest that, as in the equity market, firms with the richest information environments are least susceptible to postearnings announcement drift.

Panels A and B of Table 4 also report results for regressions of subsequent CDS returns and DSUE for subsamples of speculative and investment grade firms in both pre- and post-crisis periods. In the pre-period, only the speculative subsample exhibits a negative relation between subsequent CDS returns and DSUE. In the post-crisis period, only the speculative subsample exhibits a positive relation between subsequent CDS returns and DSUE. Hence, firms with

\footnotetext{
${ }^{12}$ Size is determined by market capitalization on a quarterly basis. At the beginning of each quarter, the sample is decomposed into terciles based on size. Because firms have varying numbers of CDSs in a given quarter, the aggregated sum of observations within each size tercile will not be equal even though the number of firms represented is.
} 
speculative grade debt are most susceptible to anomalies, consistent with the notion that the potential for accounting-based anomalies is greater for firms where accounting information is most important.

Table 5 performs this same analysis for accrual rankings. In the pre-crisis periods, underreaction to accrual information appears is greatest for the smallest group of firms and is limited to firms with speculative debt. Hence, these results are largely consistent with our prior conclusions about the role of a firm's information environment and its credit rating on its susceptibility to anomalies. In the post-crisis period, however, evidence of overreaction to accrual information is pervasive across all firm sizes and for both speculative and investment grade debt. Hence, no class of firms was immune in the post-crisis period from the CDS market's apparent overreaction.

\section{Discussion and Conclusion}

In this paper we examine the relation between post-announcement CDS returns and accounting information—quarterly deciles formed on the basis of seasonally differenced earnings and accruals — which have been shown to be associated with anomalous stock price movements. We find that both earnings surprises and accruals generate systematic patterns in subsequent CDS returns in both the pre- and post- crisis periods. This finding is consistent with the CDS market not fully impounding information efficiently. In the pre-crisis period, we find that the CDS market tends to underreact to both earnings surprises and accruals. By contrast, the CDS market tends to overreact to both with an extreme overreaction for the most negative earnings surprise and largest income decreasing accrual firms. Overall we find evidence that the CDS market suffers from similar myopia as the equity market and that its ability to price accounting information subsequent to the financial crisis was affected in economically 
meaningful ways.

In supplemental analysis, we find that the anomalous behavior observed declines with firm size. Similar to the equity market, this result indicates that firms with richer information environments are less susceptible to anomalies. Moreover, we further document that CDS mispricing is more pronounced for firms with speculative grade debt. It may be the case that accounting information is more germane in assessing default risk for speculative firms and therefore, mispricing of this information is more economically meaningful for these firms.

In summary our paper identifies inefficiencies in the credit default swap market that have several important implications. Specifically, underpricing of CDSs in the pre-crisis period would have made the purchase of CDSs more attractive to buyers. This would particularly be the case for CDSs written on firms that were rated as speculative. The incomplete CDS market response to accounting information may have contributed to the demand for CDSs written on the debt holdings of publicly traded companies which would have contributed to the massive growth of the market and the stress placed on counterparties. Because CDSs are not shorted, there does not appear to be an opportunity for abnormal returns to be earned in the post-crisis period. However, the overpricing of any security will lead to a reduction in demand and liquidity. The inefficiencies in the CDS market that have been identified here are economically significant. They are not unique to the CDS market as we observe similar inefficiencies in the equity markets as well. What is unique to the CDS market is how these inefficiencies have changed in response to the US financial crisis. The financial crisis did not lead to a change in the quality or availability of the accounting information being provided or the sophistication of CDS market participants. It is more likely that the financial crisis simply drove the market participants to use and process available information differently. It may have been a case of sunshine being the best 
disinfectant. The apparent regime shift has changes how accounting information is being used by the CDs market and time will tell if the inefficiencies that we have documented here will dissipate. 


\section{References}

Ball, R. and Brown, P. 1968. An empirical evaluation of accounting income numbers. Journal of Accounting Research 6, 169-178.

Becker, S. 2009. EMU sovereign spread widening - reasonable market reaction or exaggeration? Deutsche Bank Research. EU Monitor No. 68. June 29, 2009.

Bernard, V. L. and Thomas, J.K. 1989. Post-Earnings-Announcement Drift: Delayed Price Response or Risk Premium? Journal of Accounting Research 27, 1-36.

Callen, J.L., Livant, J., and Segal, D. 2009. The impact of earnings on the pricing of credit default swaps. The Accounting Review 84, 1363-1394.

Collins, D.W. and Hribar, P. 2000. Earnings-based and accrual-based market anomalies; one effect or two? Journal of Accounting \& Economics 29, 101-123.

DeFond, M. and Zhang, J. 2009. The asymmetric magnitude and timeliness of the reaction to earnings surprises in the corporate bond market. University of Southern California working paper.

Easton, P. D., S. J. Monahan, and F. Vasvari. 2009. Initial evidence on the role of accounting earnings in the bond market. Journal of Accounting Research 47, 721-766.

Hotchkiss, E. S., Ronen, T. 2002.The Informational Efficiency of the Corporate Bond Market: An Intraday Analysis. Review of Financial Studies 15,1325-1356.

Jiang, J. (X.). 2008. Beating earnings benchmarks and cost of debt. The Accounting Review 83, 377-416.

Katz, S. The price adjustment process of bonds to rating reclassifications: a test of bond market efficiency. Journal of Finance 74, 551-559.

Kiff, J., Elliott, J., Kazarian, E., Scarlata J. and Spackman, C. 2009. Credit derivatives: systemic risk and policy options. IMF Working Paper.

Norden, L. and Weber, M. 2004. Informational efficiency of credit default swap and stock markets: The impact of credit rating announcements. Journal of Banking \& Finance 28, 2813-2943.

Petersen, M. A. 2009. Estimating standard errors in finance panel data sets: comparing approaches. Review of Financial Studies 22, 435-480.

Sloan, R. 1996. Do stock prices fully reflect information in accruals and cash flows about future earnings? The Accounting Review 71, 289-315.

Zhu, H. 2006. An empirical comparison of credit spreads between the bond market and the credit default swap market. Journal of Financial Services Research 29, 211- 235. 
Table 1

Descriptive Statistics

Panel A: Full Sample

\begin{tabular}{|c|c|c|c|c|c|c|}
\hline Variable & $\begin{array}{c}\text { Number of } \\
\text { Observations }\end{array}$ & Mean & $\begin{array}{l}\text { Standard } \\
\text { Deviation }\end{array}$ & Lower Quartile & Median & $\begin{array}{c}\text { Upper } \\
\text { Quartile }\end{array}$ \\
\hline CDSRET60 (\%) & 11,199 & 0.190 & 1.730 & -0.099 & 0.010 & 0.327 \\
\hline CDSTRETANN(\%) & 10,331 & 0.042 & 0.380 & -0.023 & 0.000 & 0.020 \\
\hline SUE & 11,199 & -0.003 & 0.037 & -0.004 & 0.000 & 0.004 \\
\hline ACCRUALS & 11,199 & -0.015 & 0.042 & -0.022 & -0.010 & 0.000 \\
\hline SIZE (thousands) & 11,199 & 36,139 & 55,399 & 5,228 & 13,958 & 38,179 \\
\hline SPECULATIVE & 11,098 & 0.430 & 0.495 & 0 & 0 & 1 \\
\hline
\end{tabular}

Panel B: Mean (Median) Characteristics by SUE Portfolio Ranking

\begin{tabular}{lllllllllll}
\hline & \multicolumn{1}{c}{ SUE Portfolio Ranking } \\
\hline & 1 & 2 & 3 & 4 & 5 & 6 & 7 & 8 & 9 \\
CDSRET60(\%) & 0.213 & 0.061 & 0.284 & 0.198 & 0.242 & 0.272 & 0.243 & 0.069 & 0.068 & 0.215 \\
& $(0.007)$ & $(0.005)$ & $(0.010)$ & $(0.000)$ & $(0.009)$ & $(0.027)$ & $(0.018)$ & $(0.016)$ & $(0.004)$ & $(0.020)$ \\
CDSTRETANN(\%) & 0.159 & 0.108 & 0.033 & 0.053 & 0.018 & 0.015 & -0.008 & -0.003 & 0.007 & 0.045 \\
& $(0.003)$ & $(0.000)$ & $(0.000)$ & $(0.000)$ & $(0.000)$ & $(0.000)$ & $(0.000)$ & $(0.000)$ & $(-0.002)$ & $(-0.003)$ \\
SUE & -0.060 & -0.013 & -0.005 & -0.002 & -0.001 & 0.000 & 0.002 & 0.004 & 0.008 & 0.039 \\
& $(-0.022)$ & $(-0.007)$ & $(-0.003)$ & $(-0.001)$ & $(0.000)$ & $(0.001)$ & $(0.002)$ & $(0.004)$ & $(0.007)$ & $(0.023)$ \\
ACCRUAL & -0.062 & -0.020 & -0.013 & -0.009 & -0.007 & -0.007 & -0.007 & -0.009 & -0.009 & -0.008 \\
& $(-0.030)$ & $(-0.016)$ & $(-0.012)$ & $(-0.008)$ & $(-0.007)$ & $(-0.008)$ & $(0.007)$ & $(-0.008)$ & $(-0.010)$ & $(-0.008)$ \\
CASH FLOWS & 0.018 & 0.021 & 0.019 & 0.016 & 0.016 & 0.018 & 0.021 & 0.025 & 0.029 & 0.030 \\
& $(0.017)$ & $(0.020)$ & $(0.018)$ & $(0.014)$ & $(0.013)$ & $(0.019)$ & $(0.021)$ & $(0.025)$ & $(0.029)$ & $(0.030)$ \\
SIZE (thousands) & 19,606 & 21,758 & 32,532 & 53,600 & 60,284 & 40,591 & 34,391 & 33,513 & 31,973 & 24,428 \\
& $(6.983)$ & $(9,465)$ & $(12,291)$ & $(21,075)$ & $(23,166)$ & $(16,628)$ & $(15,693)$ & $(15,405)$ & $(13,566)$ & $(10,487)$ \\
SPECULATIVE & 0.617 & 0.539 & 0.417 & 0.290 & 0.259 & 0.389 & 0.386 & 0.396 & 0.497 & 0.584 \\
& $(1.000)$ & $(1.000)$ & $(0.000)$ & $(0.000)$ & $(0.000)$ & $(0.000)$ & $(0.000)$ & $(0.000)$ & $(0.000)$ & $(1.000)$ \\
\hline
\end{tabular}




\section{Table 1 continued}

Panel C: Mean (Median) Characteristics by Accrual Portfolio Ranking

\begin{tabular}{|c|c|c|c|c|c|c|c|c|c|c|}
\hline & \multicolumn{10}{|c|}{ Accrual Portfolio Ranking } \\
\hline & 1 & 2 & 3 & 4 & 5 & 6 & 7 & 8 & 9 & 10 \\
\hline CDSRET60(\%) & $\begin{array}{l}0.171 \\
(-0.005)\end{array}$ & $\begin{array}{l}0.154 \\
(0.015)\end{array}$ & $\begin{array}{l}0.108 \\
(0.013)\end{array}$ & $\begin{array}{l}0.128 \\
(0.010)\end{array}$ & $\begin{array}{l}0.342 \\
(0.010)\end{array}$ & $\begin{array}{l}0.226 \\
(-0.001)\end{array}$ & $\begin{array}{l}0.143 \\
(0.020)\end{array}$ & $\begin{array}{l}0.263 \\
(0.020)\end{array}$ & $\begin{array}{l}0.208 \\
(0.009)\end{array}$ & $\begin{array}{l}0.150 \\
(0.020)\end{array}$ \\
\hline $\begin{array}{l}\text { CDSTRETANN( } \\
\%)\end{array}$ & $\begin{array}{l}0.145 \\
(0.000)\end{array}$ & $\begin{array}{l}0.043 \\
(0.000)\end{array}$ & $\begin{array}{l}0.004 \\
(0.000)\end{array}$ & $\begin{array}{l}0.037 \\
(-0.001)\end{array}$ & $\begin{array}{l}0.025 \\
(-0.001)\end{array}$ & $\begin{array}{l}0.047 \\
(0.000)\end{array}$ & $\begin{array}{l}0.021 \\
(-0.001)\end{array}$ & $\begin{array}{l}0.019 \\
(-0.001)\end{array}$ & $\begin{array}{l}0.043 \\
(0.000)\end{array}$ & $\begin{array}{l}0.048 \\
(0.000)\end{array}$ \\
\hline SUE & $\begin{array}{l}-0.043 \\
(-0.005)\end{array}$ & $\begin{array}{l}-0.006 \\
(-0.001)\end{array}$ & $\begin{array}{l}0.000 \\
(0.000)\end{array}$ & $\begin{array}{l}0.002 \\
(0.001)\end{array}$ & $\begin{array}{l}0.000 \\
(0.000)\end{array}$ & $\begin{array}{l}0.001 \\
(0.000)\end{array}$ & $\begin{array}{l}-0.001 \\
(0.000)\end{array}$ & $\begin{array}{l}0.002 \\
(0.001)\end{array}$ & $\begin{array}{l}0.003 \\
(0.001)\end{array}$ & $\begin{array}{l}0.006 \\
(0.001)\end{array}$ \\
\hline ACCRUAL & $\begin{array}{l}-0.093 \\
(-0.061)\end{array}$ & $\begin{array}{l}-0.037 \\
(-0.028)\end{array}$ & $\begin{array}{l}-0.025 \\
(-0.021)\end{array}$ & $\begin{array}{l}-0.018 \\
(-0.016)\end{array}$ & $\begin{array}{l}-0.013 \\
(-0.012)\end{array}$ & $\begin{array}{l}-0.009 \\
(-0.008)\end{array}$ & $\begin{array}{l}-0.005 \\
(-0.005)\end{array}$ & $\begin{array}{l}0.000 \\
(0.000)\end{array}$ & $\begin{array}{l}0.007 \\
(0.006)\end{array}$ & $\begin{array}{l}0.035 \\
(0.026)\end{array}$ \\
\hline CASH FLOWS & $\begin{array}{l}0.055 \\
(0.048)\end{array}$ & $\begin{array}{l}0.037 \\
(0.036)\end{array}$ & $\begin{array}{l}0.035 \\
(0.032)\end{array}$ & $\begin{array}{l}0.029 \\
(0.028)\end{array}$ & $\begin{array}{l}0.024 \\
(0.022)\end{array}$ & $\begin{array}{l}0.020 \\
(0.017)\end{array}$ & $\begin{array}{l}0.016 \\
(0.015)\end{array}$ & $\begin{array}{l}0.013 \\
(0.011)\end{array}$ & $\begin{array}{l}0.004 \\
(0.003)\end{array}$ & $\begin{array}{l}-0.017 \\
(-0.011)\end{array}$ \\
\hline $\begin{array}{l}\text { SIZE } \\
\text { (thousands) }\end{array}$ & $\begin{array}{l}17,963 \\
(6,959)\end{array}$ & $\begin{array}{l}27, .128 \\
(11,623)\end{array}$ & $\begin{array}{l}33,402 \\
(12,596)\end{array}$ & $\begin{array}{l}40,885 \\
(15,218)\end{array}$ & $\begin{array}{l}39,119 \\
(16,725)\end{array}$ & $\begin{array}{l}45,251 \\
(18,043)\end{array}$ & $\begin{array}{l}36,058 \\
(13,652)\end{array}$ & $\begin{array}{l}40,953 \\
(15,569)\end{array}$ & $\begin{array}{l}45,280 \\
(17,880)\end{array}$ & $\begin{array}{l}33,713 \\
(12,780)\end{array}$ \\
\hline SPECULATIVE & $\begin{array}{l}0.641 \\
(1.000)\end{array}$ & $\begin{array}{l}0.553 \\
(1.000)\end{array}$ & $\begin{array}{l}0.454 \\
(0.000)\end{array}$ & $\begin{array}{l}0.441 \\
(0.000)\end{array}$ & $\begin{array}{l}0.403 \\
(0.000)\end{array}$ & $\begin{array}{l}0.308 \\
(0.000)\end{array}$ & $\begin{array}{l}0.364 \\
(0.000)\end{array}$ & $\begin{array}{l}0.345 \\
(0.000)\end{array}$ & $\begin{array}{l}0.349 \\
(0.000)\end{array}$ & $\begin{array}{l}0.466 \\
(0.000)\end{array}$ \\
\hline
\end{tabular}

Notes to Table 1:

CDSRET60 is the CDS spread on trading day 62 relative to the earnings announcement date minus the CDS spread on trading day 2 relative to the earnings announcement date; CDSTRETANN is the CDS spread on trading day 2 relative to the earnings announcement date minus the CDS spread on day -1 relative to the earnings announcement date; SUE is the seasonal difference in quarterly earnings (Compustat date item ibq) divided by average total assets; ACCRUAL is quarterly earnings minus cash flow from operations divided by average total assets; CASHFLOW is quarterly cash flow from operations; SIZE is market capitalization at the end of the quarter; SPECULATIVE is one if the firm's credit rating is below BBB+ and zero otherwise. 
Table 2

Test of the Change in the Contemporaneous CDS Response to the Announcement of Earnings and Accruals

Panel A: Earnings

DEPENDENT VARIABLE: CDSRETANN

\begin{tabular}{|c|c|c|c|c|c|c|c|c|c|c|c|c|}
\hline & \multicolumn{3}{|c|}{ Full Sample Period } & \multicolumn{3}{|c|}{ Pre-Crisis } & \multicolumn{3}{|c|}{ Post-Crisis } & \multicolumn{3}{|c|}{ Difference } \\
\hline & Coefficient & $\begin{array}{c}\mathrm{t}- \\
\text { statistic }\end{array}$ & $\begin{array}{c}\text { p- } \\
\text { value }\end{array}$ & Coefficient & $\begin{array}{c}\mathrm{t}- \\
\text { statistic }\end{array}$ & $\begin{array}{c}\text { p- } \\
\text { value }\end{array}$ & Coefficient & $\begin{array}{c}\mathrm{t}- \\
\text { statistic }\end{array}$ & $\begin{array}{c}\text { p- } \\
\text { value }\end{array}$ & Coefficient & $\begin{array}{c}\mathrm{t}- \\
\text { statistic }\end{array}$ & $\begin{array}{c}\mathrm{p}^{-} \\
\text {value }\end{array}$ \\
\hline Intercept & 0.098 & 14.20 & $<0.001$ & 0.077 & 12.93 & $<0.001$ & 0.191 & 7.39 & $<0.001$ & 0.114 & 6.52 & $<0.001$ \\
\hline DSUE & -0.114 & -9.57 & $<0.001$ & -0.095 & -9.28 & $<0.001$ & -0.196 & -4.49 & $<0.001$ & -0.101 & -3.40 & $<0.001$ \\
\hline $\mathrm{R}^{2}$ & & $0.88 \%$ & & & $1.02 \%$ & & & $1.00 \%$ & & & & \\
\hline $\mathrm{N}$ & & 10,331 & & & 8,337 & & & 1,994 & & & & \\
\hline
\end{tabular}

Panel B: Accruals

DEPENDENT VARIABLE: CDSRETANN

\begin{tabular}{|c|c|c|c|c|c|c|c|c|c|c|c|c|}
\hline & \multicolumn{3}{|c|}{ Full Sample Period } & \multicolumn{3}{|c|}{ Pre-Crisis } & \multicolumn{3}{|c|}{ Post-Crisis } & \multicolumn{3}{|c|}{ Difference } \\
\hline & Coefficient & $\begin{array}{c}\mathrm{t}- \\
\text { statistic }\end{array}$ & $\begin{array}{c}\mathrm{p}- \\
\text { value }\end{array}$ & Coefficient & $\begin{array}{c}\mathrm{t}- \\
\text { statistic }\end{array}$ & $\begin{array}{c}\text { p- } \\
\text { value }\end{array}$ & Coefficient & $\begin{array}{c}\mathrm{t}- \\
\text { statistic }\end{array}$ & $\begin{array}{c}\mathrm{p}^{-} \\
\text {value }\end{array}$ & Coefficient & $\begin{array}{c}\mathrm{t}- \\
\text { statistic }\end{array}$ & $\begin{array}{c}\mathrm{p}^{-} \\
\text {value }\end{array}$ \\
\hline Intercept & 0.063 & 9.02 & $<0.001$ & 0.029 & 4.73 & $<0.001$ & 0.207 & 8.02 & $<0.001$ & 0.178 & 10.15 & $<0.001$ \\
\hline DACCRUALS & -0.041 & -3.52 & $<0.001$ & 0.003 & 0.34 & 0.733 & -0.223 & -5.23 & $<0.001$ & -0.227 & -7.77 & $<0.001$ \\
\hline $\mathrm{R}^{2}$ & \multicolumn{3}{|c|}{0.120} & \multicolumn{3}{|c|}{$0.001 \%$} & \multicolumn{3}{|c|}{$1.36 \%$} & & & \\
\hline $\mathrm{N}$ & \multicolumn{3}{|c|}{10,331} & \multicolumn{3}{|c|}{8,337} & \multicolumn{3}{|c|}{1,994} & & & \\
\hline
\end{tabular}

Notes to Table 2:

DSUE is the within-quarter decile rank of SUE scaled to be between 0 and 1. DACCRUALS is the within-quarter decile rank of ACCRUALS scaled to be between 0 and 1 . See Table 1 for remaining variable definitions. Pre-Crisis observations are prior to September 2008 and post-crisis observations occur during or after September 2008. 
Table 3

Test of the Relation between Subsequent CDS Returns and Deciles Formed Based on Previously Announced Earnings Surprises and Accruals

Panel A: Earnings Surprises

DEPENDENT VARIABLE: CDSRET60

\begin{tabular}{|c|c|c|c|c|c|c|c|c|c|c|c|c|}
\hline & \multicolumn{3}{|c|}{ Full Sample Period } & \multicolumn{3}{|c|}{ Pre-Crisis } & \multicolumn{3}{|c|}{ Post-Crisis } & \multicolumn{3}{|c|}{ Difference } \\
\hline & Coefficient & $\begin{array}{c}\mathrm{t}- \\
\text { statistic }\end{array}$ & $\begin{array}{c}\mathrm{p}- \\
\text { value }\end{array}$ & Coefficient & $\begin{array}{c}\mathrm{t}- \\
\text { statistic }\end{array}$ & $\begin{array}{c}\mathrm{p}^{-} \\
\text {value }\end{array}$ & Coefficient & $\begin{array}{c}\mathrm{t}- \\
\text { statistic }\end{array}$ & $\begin{array}{c}\text { p- } \\
\text { value }\end{array}$ & Coefficient & $\begin{array}{c}\mathrm{t}- \\
\text { statistic }\end{array}$ & $\begin{array}{c}\mathrm{p}^{-} \\
\text {value }\end{array}$ \\
\hline Intercept & 0.214 & 7.04 & $<0.001$ & 0.571 & 20.14 & $<0.001$ & -1.448 & -15.40 & $<0.001$ & -2.019 & -26.96 & $<0.001$ \\
\hline DSUE & -0.050 & -0.96 & 0.339 & -0.276 & -5.62 & $<0.001$ & 1.058 & 6.64 & $<0.001$ & 1.333 & 10.46 & $<0.001$ \\
\hline $\mathrm{R}^{2}$ & \multicolumn{3}{|c|}{$0.01 \%$} & \multicolumn{3}{|c|}{$0.34 \%$} & \multicolumn{3}{|c|}{$2.11 \%$} & & & \\
\hline $\mathrm{N}$ & \multicolumn{3}{|c|}{11,199} & \multicolumn{3}{|c|}{9,157} & \multicolumn{3}{|c|}{2,042} & & & \\
\hline
\end{tabular}

Panel B: Accruals

DEPENDENT VARIABLE: CDSRET60

\begin{tabular}{|c|c|c|c|c|c|c|c|c|c|c|c|c|}
\hline & \multicolumn{3}{|c|}{ Full Sample Period } & \multicolumn{3}{|c|}{ Pre-Crisis } & \multicolumn{3}{|c|}{ Post-Crisis } & \multicolumn{3}{|c|}{ Difference } \\
\hline & Coefficient & $\begin{array}{c}\mathrm{t}- \\
\text { statistic }\end{array}$ & $\begin{array}{c}\mathrm{p}- \\
\text { value }\end{array}$ & Coefficient & $\begin{array}{c}\mathrm{t}- \\
\text { statistic }\end{array}$ & $\begin{array}{c}\mathrm{p}^{-} \\
\text {value }\end{array}$ & Coefficient & $\begin{array}{c}\mathrm{t}- \\
\text { statistic }\end{array}$ & $\begin{array}{c}\mathrm{p}^{-} \\
\text {value }\end{array}$ & Coefficient & $\begin{array}{c}\mathrm{t}- \\
\text { statistic }\end{array}$ & $\begin{array}{c}\text { p- } \\
\text { value }\end{array}$ \\
\hline Intercept & 0.165 & 5.36 & $<0.001$ & 0.591 & 20.58 & $<0.001$ & -1.769 & -19.07 & $<0.001$ & -2.360 & -31.54 & $<0.001$ \\
\hline DACCRUALS & 0.049 & 0.95 & 0.340 & -0.305 & -6.33 & $<0.001$ & 1.653 & 10.81 & $<0.001$ & 1.958 & 15.83 & $<0.001$ \\
\hline $\mathrm{R}^{2}$ & \multicolumn{3}{|c|}{$0.01 \%$} & \multicolumn{3}{|c|}{$0.44 \%$} & \multicolumn{3}{|c|}{$5.42 \%$} & & & \\
\hline $\mathrm{N}$ & \multicolumn{3}{|c|}{11,199} & \multicolumn{3}{|c|}{9,157} & \multicolumn{3}{|c|}{2,042} & & & \\
\hline
\end{tabular}

Notes to Table 3:

DSUE is the within-quarter decile rank of SUE scaled to be between 0 and 1. DACCRUALS is the within-quarter decile rank of ACCRUALS scaled to be between 0 and 1 . See Table 1 for remaining variable definitions. Pre-Crisis observations are prior to September 2008 and post-crisis observations occur during or after September 2008. 
Table 4

Test of Cross-sectional Differences in the Magnitude of the Relation between Subsequent CDS Returns and Deciles Formed Based on Previously Announced Earnings Surprises

Panel A: Pre-Crisis

Subsamples based on Firm Size:

\begin{tabular}{|c|c|c|c|c|c|c|c|c|c|c|c|c|}
\hline & \multicolumn{3}{|c|}{ Small } & \multicolumn{3}{|c|}{ Medium } & \multicolumn{3}{|c|}{ Large } & \multicolumn{3}{|c|}{$\begin{array}{c}\text { Difference Between Small } \\
\text { and Large }\end{array}$} \\
\hline & Coefficient & $\begin{array}{c}\mathrm{t}- \\
\text { Statistic }\end{array}$ & $\begin{array}{c}\mathrm{p}- \\
\text { value }\end{array}$ & Coefficient & $\begin{array}{c}\mathrm{t}- \\
\text { statistic }\end{array}$ & $\begin{array}{c}\text { p- } \\
\text { value }\end{array}$ & Coefficient & $\begin{array}{c}\mathrm{t}- \\
\text { statistic }\end{array}$ & $\begin{array}{c}\mathrm{p}- \\
\text { value }\end{array}$ & Coefficient & $\begin{array}{c}\mathrm{t}- \\
\text { statistic }\end{array}$ & $\begin{array}{c}\mathrm{p}- \\
\text { value }\end{array}$ \\
\hline Intercept & 0.945 & 13.98 & $<0.001$ & 0.560 & 11.75 & $<0.001$ & 0.256 & 8.44 & $<0.001$ & -0.689 & -9.97 & $<0.001$ \\
\hline DSUE & -0.422 & -3.62 & $<0.001$ & -0.316 & -3.83 & $<0.001$ & -0.021 & -0.40 & 0.693 & 0.401 & 3.36 & $<0.001$ \\
\hline $\mathrm{R}^{2}$ & \multicolumn{3}{|c|}{$0.499 \%$} & \multicolumn{3}{|c|}{$0.535 \%$} & \multicolumn{3}{|c|}{$0 . .004 \%$} & & & \\
\hline $\mathrm{N}$ & \multicolumn{3}{|c|}{2,619} & \multicolumn{3}{|c|}{2,727} & \multicolumn{3}{|c|}{ 3,811 } & & & \\
\hline
\end{tabular}

Subsamples based on Speculative Credit Rating:

\begin{tabular}{|c|c|c|c|c|c|c|c|c|c|}
\hline & \multicolumn{3}{|c|}{ Speculative } & \multicolumn{3}{|c|}{ Investment Grade } & \multicolumn{3}{|c|}{ Difference } \\
\hline & Coefficient & t-statistic & $\mathrm{p}$-value & Coefficient & t-statistic & p-value & Coefficient & t-statistic & p-value \\
\hline Intercept & 0.989 & 18.62 & $<0.001$ & 0.234 & 8.32 & $<0.001$ & 0.754 & 13.33 & $<0.001$ \\
\hline DSUE & -0.560 & -6.31 & $<0.001$ & -0.001 & -0.02 & 0.981 & -0.559 & -5.73 & $<0.001$ \\
\hline $\mathrm{R}^{2}$ & \multicolumn{3}{|c|}{$1.05 \%$} & \multicolumn{3}{|c|}{$0.000 \%$} & & & \\
\hline $\mathrm{N}$ & \multicolumn{3}{|c|}{3,762} & \multicolumn{3}{|c|}{5,317} & & & \\
\hline
\end{tabular}


Table 4, continued

Panel B: Post-Crisis

Subsamples based on Firm Size:

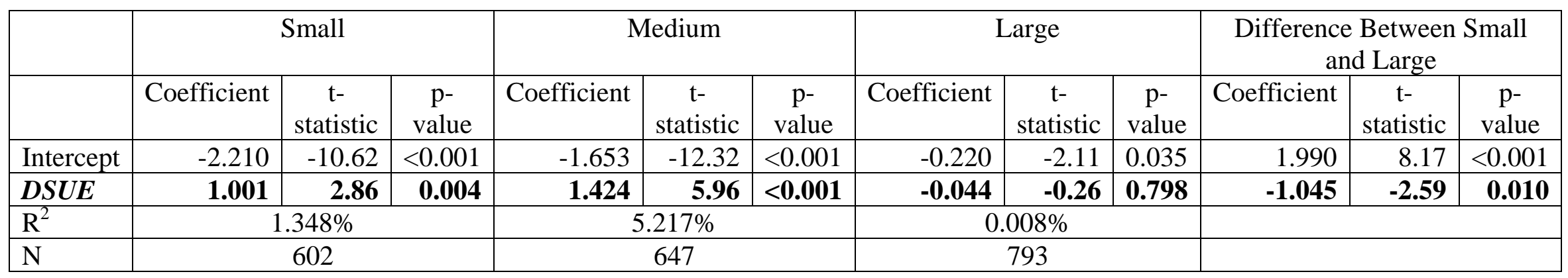

Subsamples based on Speculative Credit Rating:

\begin{tabular}{|c|c|c|c|c|c|c|c|c|c|}
\hline & \multicolumn{3}{|c|}{ Speculative } & \multicolumn{3}{|c|}{ Investment Grade } & \multicolumn{3}{|c|}{ Difference } \\
\hline & Coefficient & t-statistic & p-value & Coefficient & t-statistic & p-value & Coefficient & t-statistic & p-value \\
\hline Intercept & -2.046 & -14.42 & $<0.001$ & -0.478 & -4.46 & $<0.001$ & -1.568 & -8.17 & $<0.001$ \\
\hline DSUE & 1.183 & 4.93 & $<0.001$ & 0.292 & 1.61 & 0.108 & 0.891 & 2.74 & 0.006 \\
\hline $\mathrm{R}^{2}$ & \multicolumn{3}{|c|}{$2.344 \%$} & \multicolumn{3}{|c|}{$0.258 \%$} & & & \\
\hline $\mathrm{N}$ & \multicolumn{3}{|c|}{1,013} & \multicolumn{3}{|c|}{1,005} & & & \\
\hline
\end{tabular}

Notes to Table 4:

DSUE is the within-quarter decile rank of SUE scaled to be between 0 and 1. DACCRUALS is the within-quarter decile rank of ACCRUALS scaled to be between 0 and 1 . See Table 1 for remaining variable definitions. Pre-Crisis observations are prior to September 2008 and post-crisis observations occur during or after September 2008. 
Table 5

Test of Cross-sectional Differences in the Magnitude of the Relation between Subsequent CDS Returns and Deciles Formed Based on Previously Announced Accruals

Panel A: Pre-Crisis

Subsamples based on Firm Size:

\begin{tabular}{|c|c|c|c|c|c|c|c|c|c|c|c|c|}
\hline & \multicolumn{3}{|c|}{ Small } & \multicolumn{3}{|c|}{ Medium } & \multicolumn{3}{|c|}{ Large } & \multicolumn{3}{|c|}{$\begin{array}{l}\text { Difference Between Small } \\
\text { and Large }\end{array}$} \\
\hline & Coeff & t-statistic & p-value & Coeff & t-statistic & p-value & Coeff & t-statistic & p-value & Coeff & t-statistic & p-value \\
\hline Intercept & 1.020 & 14.89 & $<0.001$ & 0.438 & 9.15 & $<0.001$ & 0.317 & 10.27 & $<0.001$ & -0.703 & -10.04 & $<0.001$ \\
\hline DACCRUALS & -0.575 & -4.89 & $<0.001$ & -0.064 & -0.80 & 0.423 & -0.133 & -2.63 & 0.009 & 0.442 & 3.75 & $<0.001$ \\
\hline $\mathrm{R}^{2}$ & \multicolumn{3}{|c|}{$0.905 \%$} & \multicolumn{3}{|c|}{$0.024 \%$} & \multicolumn{3}{|c|}{$0.18 \%$} & & & \\
\hline $\mathrm{N}$ & \multicolumn{3}{|c|}{2,619} & \multicolumn{3}{|c|}{2,727} & \multicolumn{3}{|c|}{3,811} & & & \\
\hline
\end{tabular}

Subsamples based on Speculative Credit Rating:

\begin{tabular}{|c|c|c|c|c|c|c|c|c|c|}
\hline & \multicolumn{3}{|c|}{ Speculative } & \multicolumn{3}{|c|}{ Investment Grade } & \multicolumn{3}{|c|}{ Difference } \\
\hline & Coefficient & t-statistic & p-value & Coefficient & t-statistic & p-value & Coefficient & t-statistic & p-value \\
\hline Intercept & 1.010 & 19.49 & $<0.001$ & 0.156 & 5.31 & $<0.001$ & 0.854 & 14.98 & $<0.001$ \\
\hline DACCRUALS & -0.636 & -7.05 & $<0.001$ & 0.145 & 3.03 & 0.002 & -0.781 & -8.13 & $<0.001$ \\
\hline $\mathrm{R}^{2}$ & & $1.306 \%$ & & & $0.173 \%$ & & & & \\
\hline $\mathrm{N}$ & & 3,762 & & & 5,317 & & & & \\
\hline
\end{tabular}


Table 5, continued

Panel B: Post-Crisis

Subsamples based on Firm Size:

\begin{tabular}{|c|c|c|c|c|c|c|c|c|c|c|c|c|}
\hline & \multicolumn{3}{|c|}{ Small } & \multicolumn{3}{|c|}{ Medium } & \multicolumn{3}{|c|}{ Large } & \multicolumn{3}{|c|}{$\begin{array}{c}\text { Difference Between Small } \\
\text { and Large }\end{array}$} \\
\hline & Coefficient & $\begin{array}{c}\mathrm{t}- \\
\text { statistic }\end{array}$ & $\begin{array}{c}\mathrm{p}^{-} \\
\text {value }\end{array}$ & Coefficient & $\begin{array}{c}\mathrm{t}- \\
\text { Statistic }\end{array}$ & $\begin{array}{c}\mathrm{p}- \\
\text { value }\end{array}$ & Coefficient & $\begin{array}{c}\mathrm{t}- \\
\text { statistic }\end{array}$ & $\begin{array}{c}\mathrm{p}- \\
\text { value }\end{array}$ & Coefficient & $\begin{array}{c}\mathrm{t}- \\
\text { statistic }\end{array}$ & $\begin{array}{c}\mathrm{p}- \\
\text { value }\end{array}$ \\
\hline Intercept & -2.192 & -10.98 & $<0.001$ & -1.837 & -12.94 & $<0.001$ & -0.648 & -6.24 & $<0.001$ & 1.544 & 6.41 & $<0.001$ \\
\hline DACCRUALS & 1.243 & 2.96 & 0.003 & 1.620 & 7.00 & $<0.001$ & 0.653 & 4.31 & $<0.001$ & -0.590 & -1.43 & 0.153 \\
\hline $\mathrm{R}^{2}$ & \multicolumn{3}{|c|}{$1.439 \%$} & \multicolumn{3}{|c|}{$7.06 \%$} & \multicolumn{3}{|c|}{$2.29 \%$} & & & \\
\hline $\mathrm{N}$ & \multicolumn{3}{|c|}{602} & \multicolumn{3}{|c|}{647} & \multicolumn{3}{|c|}{793} & & & \\
\hline
\end{tabular}

Subsamples based on Speculative Credit Rating:

\begin{tabular}{|c|c|c|c|c|c|c|c|c|c|}
\hline & \multicolumn{3}{|c|}{ Speculative } & \multicolumn{3}{|c|}{ Investment Grade } & \multicolumn{3}{|c|}{ Difference } \\
\hline & Coefficient & t-statistic & p-value & Coefficient & t-statistic & p-value & Coefficient & t-statistic & p-value \\
\hline Intercept & -2.142 & -15.29 & $<0.001$ & -0.890 & -8.26 & $<0.001$ & -1.252 & -6.51 & $<0.001$ \\
\hline DACCRUALS & 1.505 & 5.87 & $<0.001$ & 0.951 & 5.86 & $<0.001$ & 0.554 & 1.77 & $\mathbf{0 . 0 7 7}$ \\
\hline $\mathrm{R}^{2}$ & & $3.300 \%$ & & & $3.309 \%$ & & & & \\
\hline $\mathrm{N}$ & & 1,013 & & & 1,006 & & & & \\
\hline
\end{tabular}

Notes to Table 5:

$D S U E$ is the within-quarter decile rank of $S U E$ scaled to be between 0 and 1 . DACCRUALS is the within-quarter decile rank of ACCRUALS scaled to be between 0 and 1 . See Table 1 for remaining variable definitions. Pre-Crisis observations are prior to September 2008 and post-crisis observations occur during or after September 2008. 
Figure 1

Graph of Cumulated Returns for Credit Default Swaps from 2003-2009 Decomposed into Standardized Unexpected Earnings Deciles for 90 Days after the Earnings Announcement.

Panel A: For the entire sample period.

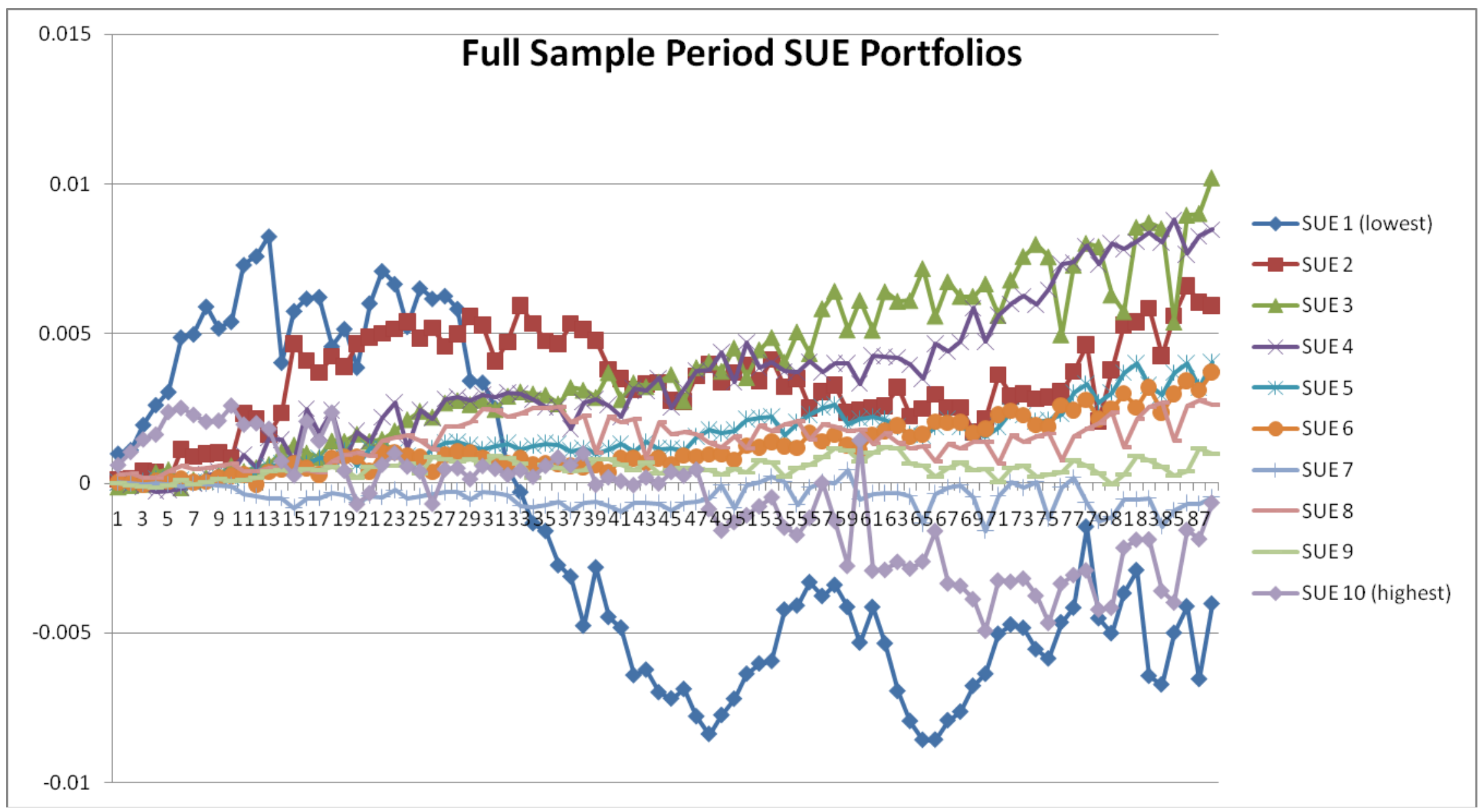


Panel B: For the pre-crisis period

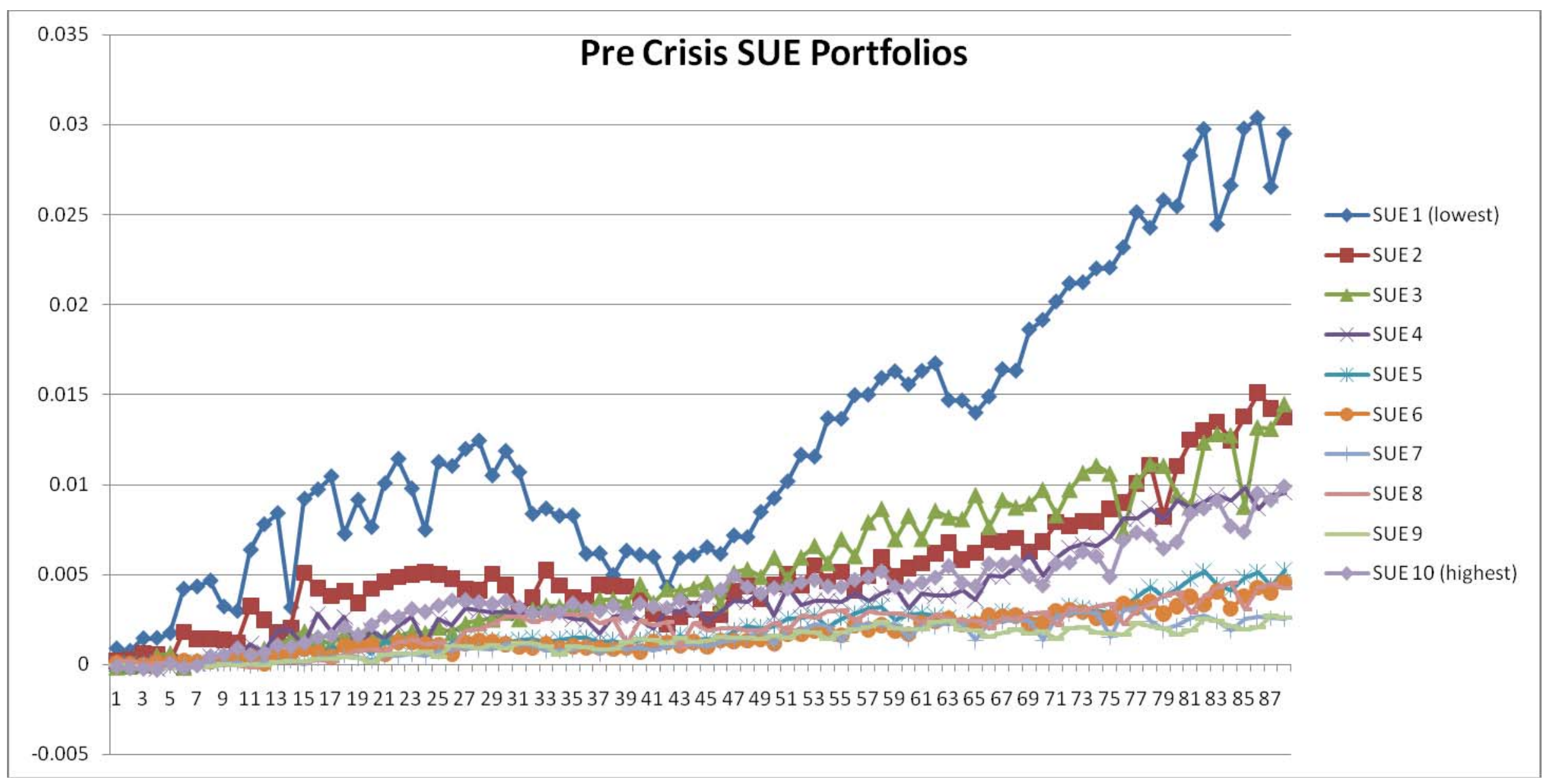


Figure 1, continued

Panel C: For the post-crisis period

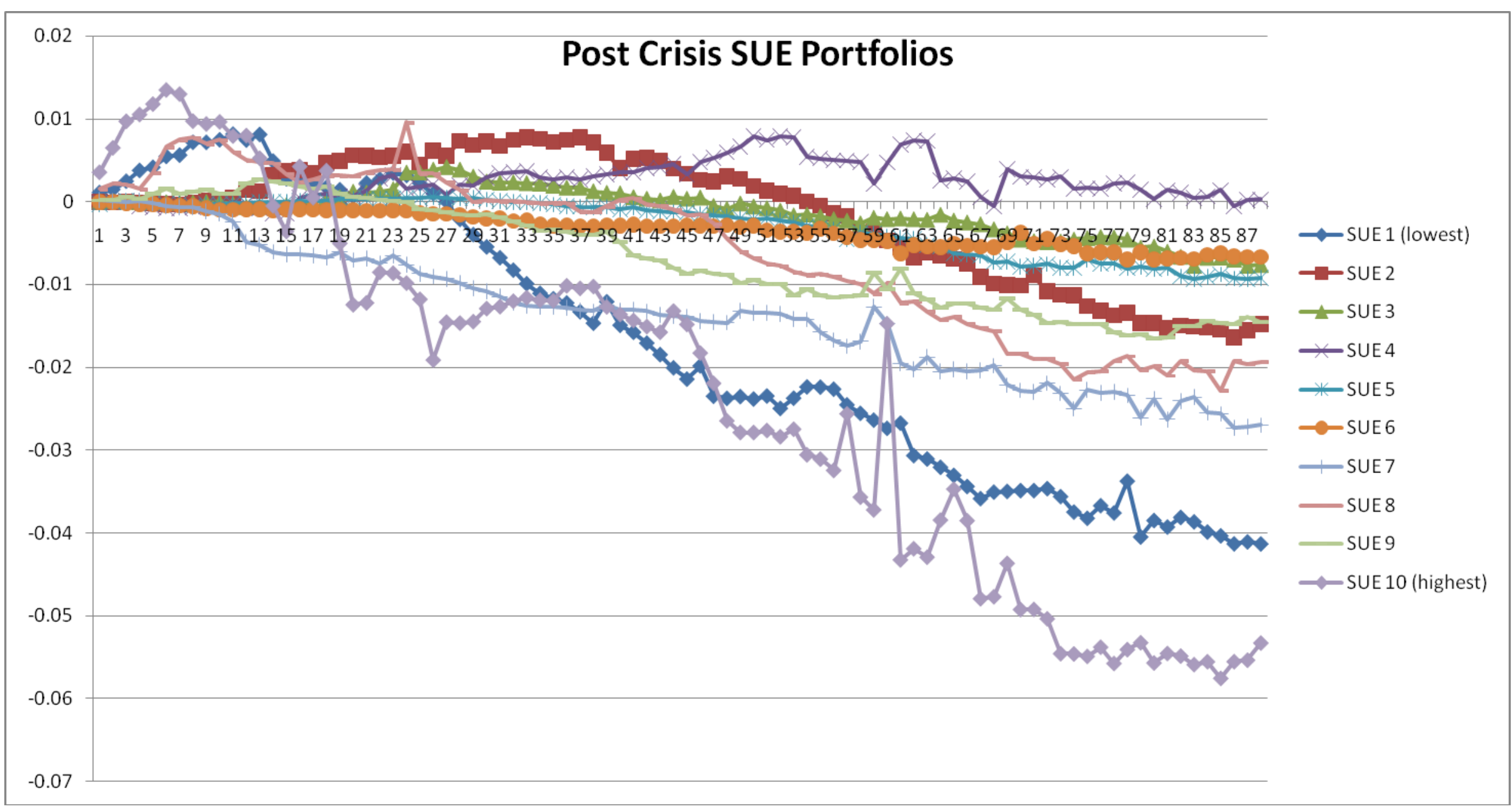


Figure 2

Graph of Cumulated Returns for Credit Default Swaps from 2003-2009 Decomposed into Accrual Deciles for 90 Days after the Earnings Announcement.

Panel A: For the entire sample period

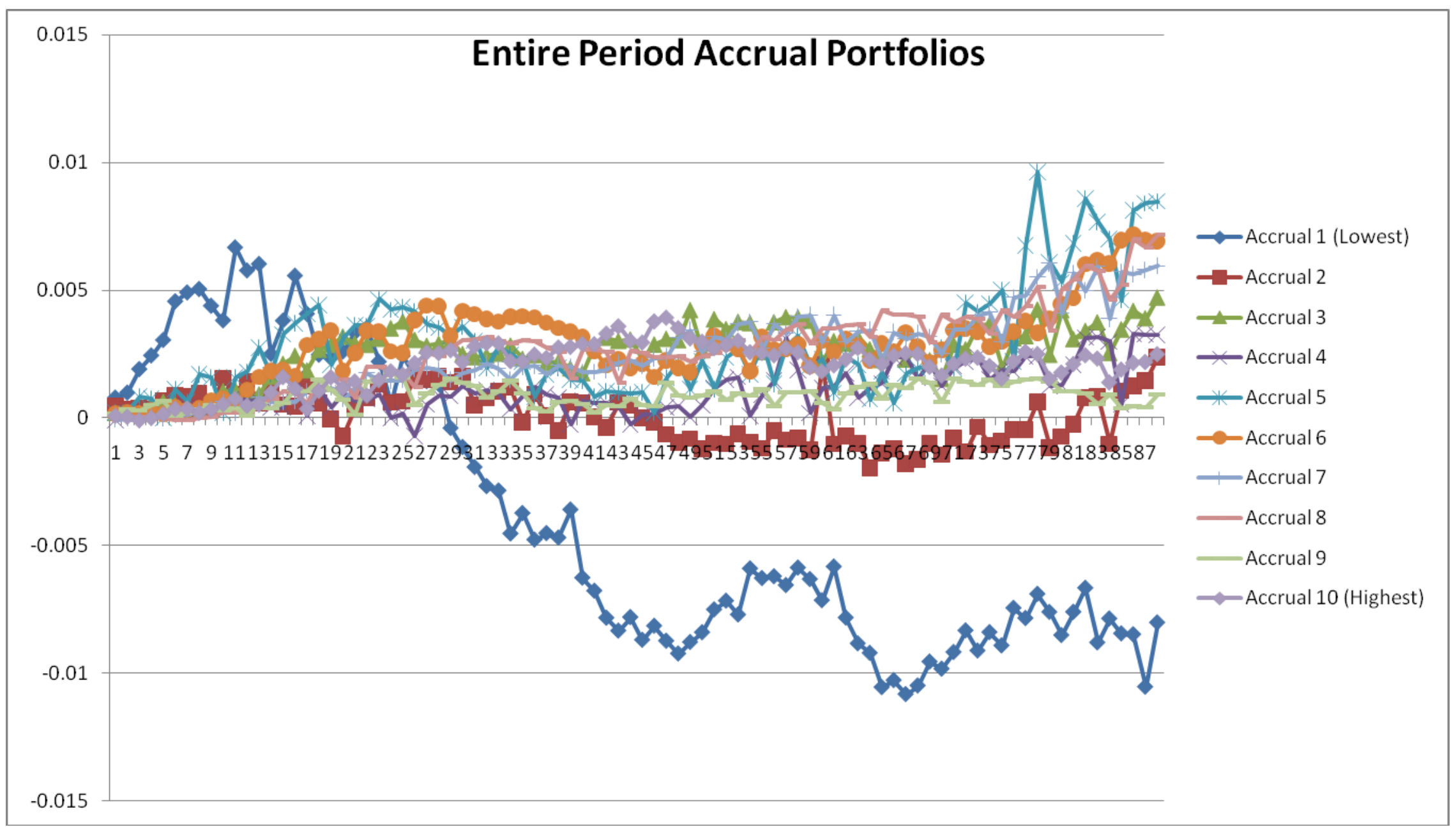


Panel B: For the pre-crisis period

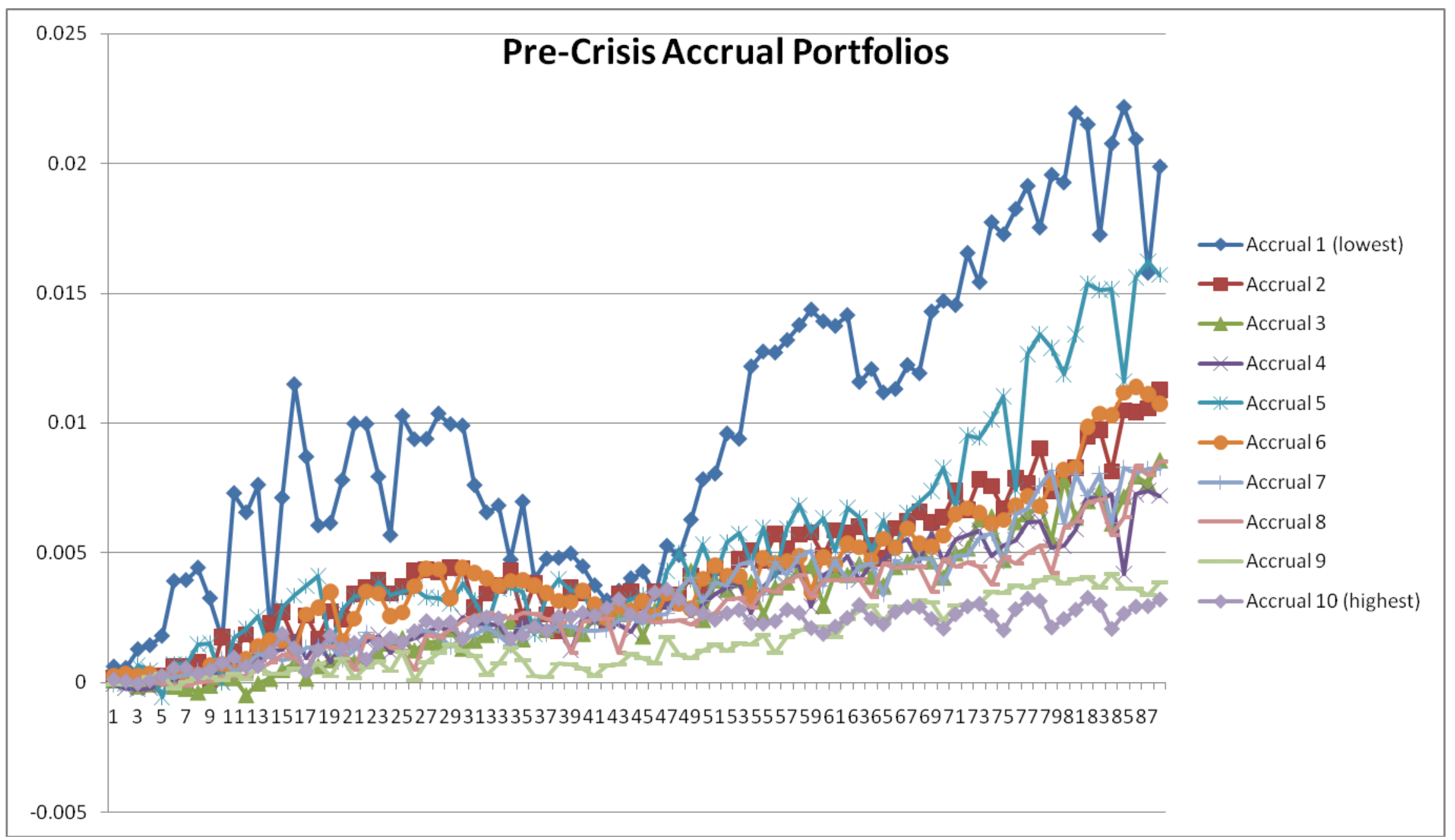


Figure 2, continued

Panel C: For the post-crisis period

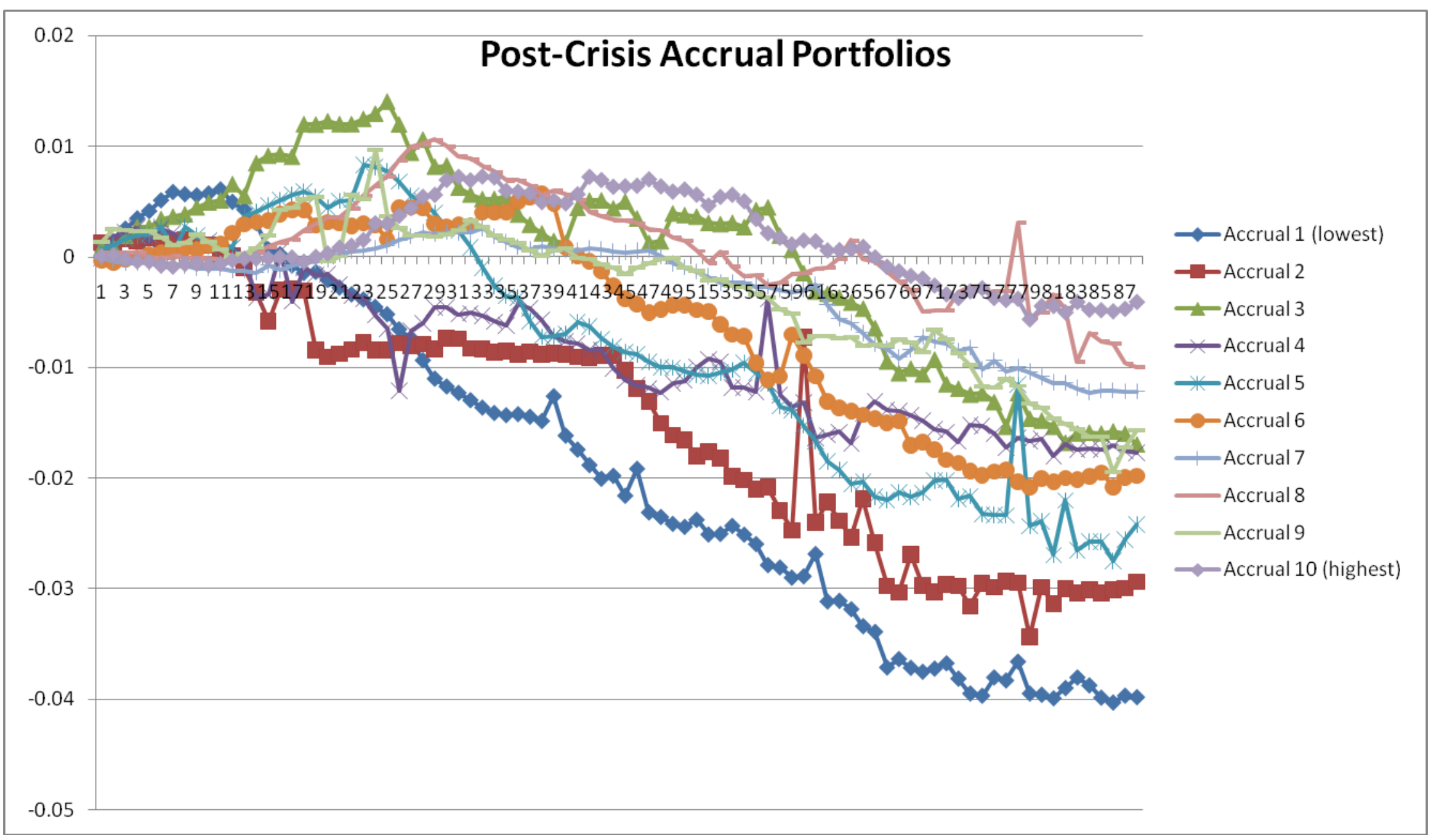

